\title{
IMPLEMENTASI MODEL INQUIRY BASED LEARNING (IBL) BERBANTUAN MEDIA PERMAINAN KATA-LIST TERHADAP MOTIVASI DAN HASIL BELAJAR SISWA PADA MATERI KESETIMBANGAN ION DAN pH LARUTAN PENYANGGA
}

\section{The Implemention of Inquiry Based Learning (IBL) Model Assisted Kata- list Media Play on The Motivation and Learning Outcomes Results of Students in the Equilibrium Ion and pH Buffer Solution}

Linda Safitri*, Parham Saadi, Rusmansyah

Program Studi Pendidikan Kimia FKIP Universitas Lambung Mangkurat, Jl. Brigjend. H. Hasan Basry Banjarmasin 70123 Kalimantan Selatan Indonesia *email: $\underline{\text { lindasafitri1004@gmail.com }}$

\begin{abstract}
Abstrak. Telah dilakukan penelitian tentang implementasi model inquiry based learning (IBL) berbantuan media perminan kata-list terhadap motivasi dan hasil belajar. Penelitian ini bertujuan untuk mengetahui (1) perbedaan pada motivasi siswa, (2) perbedaan pada hasil belajar, (3) hubungan antara motivasi dan hasil belajar, (4) respon siswa. Metode penelitian ini adalah quasi experiment dengan desain equivalent control group. Sampel penelitian adalah kelas MIA 3 sebagai kelas kontrol dan MIA 1 sebagai kelas eksperimen di SMA Negeri 10 Banjarmasin. Variabel bebas adalah model IBL berbantuan media permainan kata-list, sedangkan variabel terikat adalah hasil belajar dan motivasi. Data dikumpulkan menggunakan teknik non-tes dan tes. Inferensial dan dekriptif merupakan teknik analisis data yang digunakan. Hasil yang diperoleh menunjukan adanya (1) perbedaan motivasi secara signifikan antara pembelajaran yang menerapkan pendekatan saintifik dengan berbantuan media permainan kata-list dan pembelajaran dengan pendekatan saintifik, (2) perbedaan hasil belajar pengetahuan yang signifikan pada pembelajaran yang menerapkan pendekatan sainfitik dengan berbantuan media permaianan katalist dan pembelajaran dengan pendekatan saintifik, (3) hubungan positif antara motivasi dengan hasil belajar siswa, (4) siswa memberi respon sangat positif terhadap pembelajaran yang menerapkan model IBL berbantuan media permainan kata-list.
\end{abstract}

Kata Kunci: IBL, media permainan kata-list, motivasi, hasil belajar, kesetimbangan ion dan $\mathrm{pH}$ larutan penyangga.

\begin{abstract}
A research has been carried out on the implementation of inquiry based learning (IBL) model assisted by the kata-list media on motivation and learning outcomes. This study aims to determine (1) differences in student motivation, (2) differences in learning outcomes, (3) the relationship between motivation and learning outcomes, (4) student responses. This research method is a quasi experiment with an equivalent control group design. The research sample is MIA 3 class as a control class and MIA 1 as an experimental class in SMA Negeri 10 Banjarmasin. The independent variable is the IBL model assisted by kata-list play media, while the dependent variable is learning outcomes and motivation. Data was collected using non-test and test techniques. Inferential and descriptive data analysis techniques are used. The results obtained indicate that (1) a significant difference in motivation between learning that applies a scientific approach with the aid of kata-list play media and learning with a scientific approach, (2) a significant difference in learning outcomes in learning that applies a scientific approach to media-assisted learning kata-list and learning with a scientific approach, (3) a positive relationship between motivation and student learning outcomes, (4) students
\end{abstract}


respond very positively to learning that applies the IBL model assisted by katalist play media.

Keywords: IBL, kata-list play media, motivation, learning outcomes, Equilibrium Ion and pH Buffer Solution.

\section{PENDAHULUAN}

Pendidikan di Indonesia seiring perkembangan zaman menuntut kualitas pendidikan yang lebih baik lagi. Bangsa Indonesia dituntut untuk mengembangakan SDM yang memiliki kompetensi dan keahlian. Banyaknya kompetensi dan keahlian yang harus dimiliki mengharuskan perbaikan terus menerus dalam bidang pendidikan. Kurikulum, guru, sarana \& prasarana serta siswa merupakan komponen yang mempengaruhi pelaksanaaan pendidikan. Hal paling mendasar yang diperlukan agar terlaksana pendidikan yang diharapkan adalah keinginan siswa itu sendiri untuk ikut terlibat dalam proses belajar yang sudah direncanakan.

Berdasarkan observasi kegiatan siswa selama PPL dan wawancara dengan guru kimia di SMAN 10 Banjarmasin, menunjukkan mereka masih mengalami kesulitan dalam mempelajari kimia karena kurangnya keingintahuan pada pelajaran kimia khususya perhitungan. Salah satu materi yang dianggap sulit yaitu kesetimbangan ion dan $\mathrm{pH}$ larutan penyanggga karena terdapat banyak perhitungan. Menurut guru kimia sebanyak $40 \%$ siswa dapat mencapai ketuntasan belajar dan $60 \%$ belum mencapai kreteria ketuntasan minimal pada ulangan harian. Menurut Puspita \& Syahmani (2016) kesulitan dalam materi penyaangga ini dilihat dari hasil belajar yang masih tergolong rendah.

Menggunakan model yang tepat akan membuat pembelajaran berjalan dengan lebih baik. Model IBL adalah model pembelajaran yang menekankan berpusat pada siswa serta melibatkan dalam penyelidikan masalah. Farhan \& Retnawati (2014) mengatakan inquiry based learning berpengaruh dilihat dari prestasi \& motivasi dikarenakan memiliki karakter yang membantu peningkatan kemampuan. Modell IBL mampu mengembangkan potensi siswa seperti berpikir secara sistematis, kritis,serta logis karena model ini menekankan pada kegiatan mencaridan menemukan jawaban seorang diri dari masalah yang dipertanyakan (Fatonah, Ashadi, \& Haryono, 2016). Siswa aktif serta mampu mengkontruksikan pengetahuan secara mandiri dengan model IBL (Fitriyani, Darwis, \& Kartika, 2017).

Selain menggunakan model pembelajaran dapat pula dibantu menggunakan media pembelajaran. Media dapat membantu siswadalam memusatkan perhatian, merangsang keingintahuan, membangkitkan motivasi belajar, dan membantu mencapai ketuntasan belajar. Sejalan dengan pendapat Ismail, Enawaty dan Lestari (2018) penggunaan media membuat kegiatan pembelajarann menjadi menarik perhatian sehingga membuat siswa menjadi lebih aktif.

Permainan kata-list merupakan media yang dapat dgunakan untuk membantu pembelajaran. Permainan pada media kata-list membuat pembelajaran menjadi lebih menyenangkan sehingga meningkatkan minat juga motivasi untuk mendapat hasil belajar yang optimal. Rahmadani, Rasmiwetti, \& Azmi (2015) berpendapat bahwa media permainan dapat membuat siswa menjadi lebih termotivasi dalam belajar dan menciptakan suasana yang menyenangkan didalam kelas (Rahmadani, Rasmiwetti, \& Azmi, 2015).

Pada latar belakang yang sudah diuraikan diatas, penelitian ini dibuat sebagai kajian untuk peningkatkan motivasi dan hasilbelajar siswa menggunakan model IBL berbantuan permainan kata-list pada pembahasan kesetimbangan ion \& $\mathrm{pH}$ larutan penyangga. 


\section{METODE PENELITIAN}

Rancangan penelitian ini menggunakan quasi eksperiment dengan desain pretest-posttest equivalent control group design. Sampel penelitian menggunakan 2 kelas yang dipilih dari 3 kelas yang tersedia dengan menggunakan teknik purposive sampling, masing-masing sebanyak 33 orang pada kelass XI MIA 1 (eksperimen) dan XI MIA 3 kelas (kontrol). Penelitian dilakukan dari bulan April-Mei 2019 di SMAN 10 Banjarmasin. Setiap kelas dilakukan 3x pertemuan untuk pembelajaran. Kelas eksperimen menerapkan model IBL berbantuan media pemainan kata-list, sedangkan kelas kontrol menerapkan model IBL.

Data dikumpulkan dengan menggunakan teknik nontes dan tes. Teknik nontes dipakai untuk mengumpulkan data motivasi belajar dengan menggunakan angket, hasil belajar sikap dan keterampilan dengan menggunakan lembar observasi. Selain itu untuk mengetahui respon siswa pada pembelajara digunakan angket respon, sedangkan teknik tes digunakan untuk mengumpulkan data hasil belajar pengetahuan menggunakan 15 soal pilihan ganda, sedangkan

Perangkat penelitian berupa silabus, RPP, dan LKPD. Analisis deskriptif dengan inferensial merupakan teknik analisis yang digunakan. Penggunaan Analisis deskriptif untuk menganalisis motivasi, hasil belajar serta respon siswa. Analisis inferensial menggunakanguji-t untuk menganalisis perbedaan motivasi belajar dan hasil belajar pengetahuan. Selain itu juga digunakan uji korelasi product moment untuk mengetahui hubungan motivasi dan hasilsbelajar pengetahuan.

\section{HASIL PENELITIAN DAN PEMBAHASAN}

\section{Analisis Motivasi Siswa}

Penyelidikan yang didapat pada aspek motivasi menurut Keller (2010) terdiri atas 4 komponen, yakni (1) Attention (2) relevance keterkaitan (3) confidence (4) Satisfaction atau kepuasan dapat dilihat pada Tabel 1.

Tabel 1. Presentase pencapaian tiap komponen motivasi siswa

\begin{tabular}{ccccccccc}
\hline \multirow{2}{*}{ Komponen } & \multicolumn{4}{c}{ Eksperimen } & \multicolumn{4}{c}{ Kontrol, } \\
\cline { 2 - 9 } & Pra-treatmet & \multicolumn{2}{c}{$\begin{array}{c}\text { Post.- } \\
\text { treatment }\end{array}$} & Pra-treatment & \multicolumn{2}{c}{$\begin{array}{c}\text { Post- } \\
\text { treatment }\end{array}$} \\
\cline { 2 - 10 } & $\%$ & Kualifikasi & $\%$ & Kualifikasi & $\%$ & Kualifikasi & $\%$ & Kualifikasi \\
\hline Attention & 56,21 & Cukup & 91,67 & Sangat baik & 67,58 & Cukup & 76,77 & Baik \\
\hline Relevance & 63,57 & Cukup & 90,98 & Sangat baik & 71,45 & Baik & 78,05 & Baik \\
\hline Convidence & 55,02 & Cukup & 90,91 & Sangat baik & 65,52 & Cukup & 76,50 & Baik \\
\hline Satisfaction & 67,27 & Cukup & 91,31 & Sangat baik & 73,94 & Baik & 77,37 & Baik \\
\hline
\end{tabular}

Berdasarkan Tabel 1, pada post-treatment kelas eksperimen semua komponen motivasi memiliki pencapaian sangat baik, sedangkan pada kelas kontrol memiliki pencapaian baik. Hasil uji-t terhadap nilai rata-rataa kkelas eksperimen serta kontrol tersaji pada Tabel2. Interpretasi $N$-gain tersaji di Tabel 3.

Tabel 2. Uji-t

\begin{tabular}{cccccccc}
\hline Kelas & $\mathbf{n}$ & Mean & SD & SD $^{\mathbf{2}}$ & $\mathbf{T}_{\text {hitung }}$ & $\begin{array}{c}\mathbf{T}_{\text {table }} \\
\mathbf{5 \%}\end{array}$ & Kesimpulan \\
\hline $\begin{array}{c}\text { Eksperimen } \\
\text { Kontrol }\end{array}$ & 33 & 80,03 & 3,98 & 15,80 & 4,77 & 2,00 & Signifikan \\
\hline
\end{tabular}


Tabel 3. Interpretasi $N$-gain Motivasi

\begin{tabular}{ccc}
\hline Kelas & $N$-gain Rata-rata & Kualifikasi \\
\hline Kelas Eksperimen & 0,52 & Sedang \\
Kelas Kontrol & 0,40 & Sedang \\
\hline
\end{tabular}

Motivasi siswa pada Tabel 2 memperlihatkan adanya perbedaan signifikan pada kelas yang diterapkannya model IBL berbantuan media permaianan kata-list dan kelas yang menerapkan model IBL. Berdasarkan data tersebut, dapat ditarik kesimpulan bahwa model IBL berbantuan media kata-list memberikan pengaruh positif tehadap motivasi siswa.

Motivasi siswa dikelas eksperiment dan kontrol memiliki perbedaan peningkatan sebagai akibat adanya perlakuan aktivitas yang beda. Aktivitas pembelajaran dengan penerapan model IBL berbantuan media permainan kata-list akan lebih efektif meningkat motivasi siswa ini dikarenakan adanya penggunaaan media.Menurut Ekayani (2017) Media digunakan sebagai alat bantu dalam mengajar, merangsang pikiran, perhatian, perasaan, serta kemampuan/keterampilan siswa sehingga proses belajar dapat terjadinya dengan baik di dlam kelas.

\section{Analisis Sikap Siswa}

Penggunaan mdel IBL brbantuan media permainan kata-list ini selain memberi pengaruh pada motivasi siswa juga berdampak positif dalam hasil belajar sikap siswa kelas kntrol dan ekperimen. Perolehan rata-rata nilai sikap kelas siswa pada eksperimenn dan pada kelas konrol digambarkan dalam bentuk grafik dan tersaji dalam Gambar 1 di bawah ini

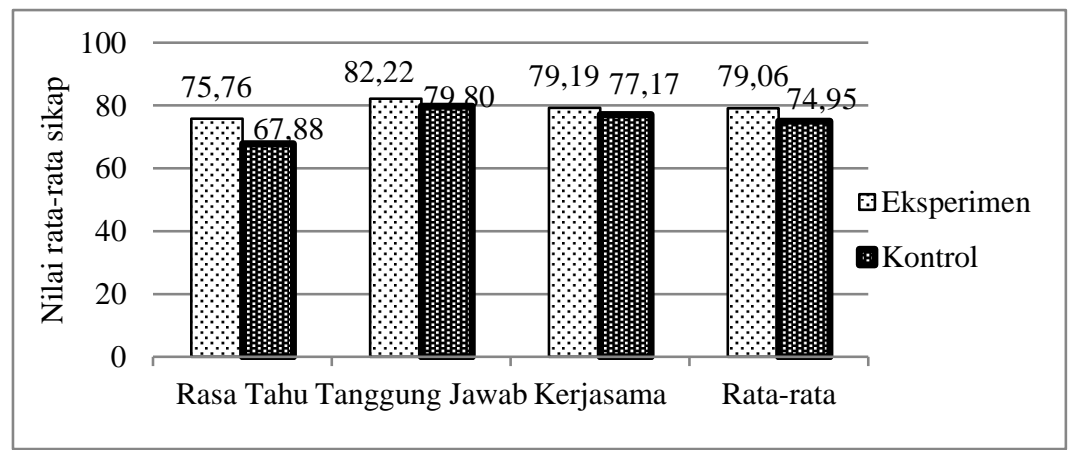

Gambar 1. Perbandingan Hasil belajar sikap

Berdasarkan Gambar 1, hasil belajar sikap rata-rata siswa lebih tinggi kelas eksperimen pada setiap aspek yang diamati maka menunjukkan bahwa secara keseluruhan penggunaan model IBL dibantu media permainan kata-list dalam pembelajaraan, memberikan hasil yang positif terhadap sikap siswa. Hasil temuan sejalan dengan penelitian Salipah, Sudirman, \& Haryani (2016) yang mengatakan model inkuiri dalam pembelajaraan dengan dibantu media dapat memberikan pengaruh yang lebih baik pada sikap siswa selama proses belajar mengajar berlangsung. 


\section{Analisis Hasil Belajar Pengetahuan}

Pada penelitian ini selain motivasi belajar juga mengukur hasil belajar pengetahuan terhadap penggunaaan modell IBL dibantu permainan kata-list. Uji-t dan $N$-gain yang diperoleh dapat dilihat pada Tabel 4 dan 5.

Tabel 4. Hasil uji-t data pre-test dan post-test pengetahuan

\begin{tabular}{cccccccc}
\hline Kelas & $\mathbf{N}$ & Mean & SD & SD $^{\mathbf{2}}$ & $\mathbf{T}_{\text {hitung }}$ & $\begin{array}{c}\mathbf{T}_{\text {table }} \\
\mathbf{5 \%}\end{array}$ & Kesimpulan \\
\hline Eksperimen & 33 & 90,50 & 7,08 & 50,12 & 3,13 & 2,00 & Signifikan \\
Kontrol & 33 & 85,04 & 6,88 & 47,30 & & & \\
\hline
\end{tabular}

Tabel 5. Interpretasi $N$-gain.

\begin{tabular}{ccc}
\hline Kelas & Rata-Rata $\boldsymbol{N}$-gain & Kualifikasi \\
\hline Kelas Eksperimen & 0,87 & Tinggi \\
Kelas Kontrol & 0,79 & Tinggi \\
\hline
\end{tabular}

Tabel 4 menunjukkan perbedaan yang signifikan di kedua kelas. Pada Tabel 5 memperlihatkan seberapa besar perbedaan $N$-gain rata-rata ekssperimen dengan control yang diperoleh. $N$-gain pada kelas eksperimen dan kelas kontrol berada dalam kualifikasi tinggi, sehingga dapat dikatakan siswa pada dikedua kelas memiliki peningkatan pengetahuan baik pada pembahasan kesetimbangan ion \& $\mathrm{pH}$ larutan penyangga.

Peningkatan pada ranah pengetahuan dikelas ekperimen maupun kontrol sebagai akibat adanya perbedaan perlakuan yang dilakukan oleh guru. Penggunaan model IBL berbantuan media permainan kata-list lebih efektif dalam meningkatan hasil belajar pengetahuan, hal ini dikarenakan penggunaan model IBL membuat siswa menemukan konsepnya sendiri sehingga membuat pembelajaran yang didapatkan lebih bermakna sedangkan penggunaan media permainan kata-list membantu melatih siswa untuk menjawab soal-soal terkait materi pembelajaran dengan cara yang menyenangkan, sehingga siswa memiliki pemahamann yang lebih baik.

Temuan penelitian sejalan dengan penelitian yang dilakukan Tyas, \& Lazulva (2018) yang menyatakan penggunaan model inquiry dibantu media pembelajaran menciptakan peningkatan hasil belajar siswa yang lebih baik dikarenakan pembelajaran yang diterapkan memudahkan siswadalam memahami materi.

Menurut Septiani, Sumarni, \& Saptorini (2014) menerapkan model IBL berbantuan media akan lebih efektif dalam meningkatkan pemahaman konsep. Salam, Muharram dan Aulia (2016) menyatakan bahwa psiswa lebih trtarik dengan penggunaan media dalam proses belajar sehingga akan sangat mendukung hasil belajar yang dipeoleh.

\section{Analisis Keterampilan Siswa}

Pada Gambar 2 memperlihatkan keterampilan siswa kelas control dan eksperimen dalam bentuk grafik. Pada Gambar2, keterampilan rata-rata siswa kelas eksperimen lebih efektik dalam meningkatkan keterampilan siswa. Menurut Syah (2003) keberhasilan pada ranah pengetahuan akan berdampak pada ranah keterampilan. Keterampilan merupakan perwujudan dari pengetahuan dan sikap dari siswa. 


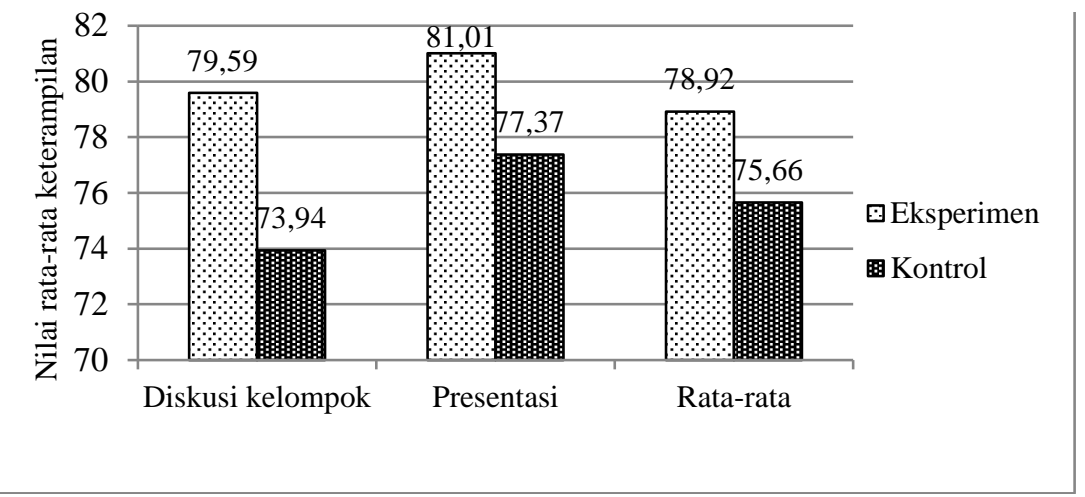

Gambar 2. Perbandingan hasil belajar keterampilan

\section{Hubungan Motivasi Dan Hasil Belajar}

Motivasi dan hasil belajar pengetahuan yang dimiliki siswa juga memiliki hubungan yang signifikan, hal ini ditunjukkan melalui harga $r$ yang diperoleh melalui uji korelasi product moment yang dapat dilihat pada tabel 6 .

Tabel 6. Hasil koefisien korelasi

\begin{tabular}{|c|c|c|c|}
\hline Kelas & & & Kesimpulan \\
\hline \multirow{4}{*}{ Eksperimen } & $r_{\text {hitung }}$ & 0,543 & \multirow{2}{*}{ Terdapat hubungan positif dengan kekuatan hubungan "sedang" } \\
\hline & $r_{\text {tabel }}$ & 0,344 & \\
\hline & $t_{\text {hitung }}$ & 3,597 & \multirow{2}{*}{ Terdapat hubungan signifikan } \\
\hline & $\mathrm{t}_{\text {tabel }}$ & 2,040 & \\
\hline \multirow{4}{*}{ Kontrol } & $r_{\text {hitung }}$ & 0,394 & \multirow{2}{*}{ Terdapat hubungan positif dengan kekuatan hubungan "rendah" } \\
\hline & $\mathrm{r}_{\text {tabel }}$ & 0,344 & \\
\hline & $t_{\text {hitung }}$ & 2,212 & \multirow{2}{*}{ Terdapat hubungan signifikan } \\
\hline & $\mathrm{t}_{\text {tabel }}$ & 2,040 & \\
\hline
\end{tabular}

Pada Tabel 5 menunjukkan besarnya hubungan positif diantara hasil dengan motivasi pengetahuan kelas komtrol dan eksperimen. Siswa yang meraih hasil belajar yang tinggi akan memiliki motivasi belajar lebih baik dibandingkan siswa yang memiliki hasil belajar lebih rendah, hal ini sejalan dengan penelitian yang dilakukan Jafar, Side, \& Maryono (2018) bahwa motivasi dan hasil belajar yang dimiliki siswa mempunyai korelasi atau hubungan yang signifikan.

Berdasarkan penelitian Nurdin, Sulastry, \& Hasri (2018) menunjukkan bahwa media pembelajaran dengan model pembelajaran lebih baik dibandingkan tanpa penggunaan media.

\section{Analisis Respon Siswa}

Hasil respon siswa terhadap model IBL berbantuan media permainan kata-list tersaji pada Gambar 3.

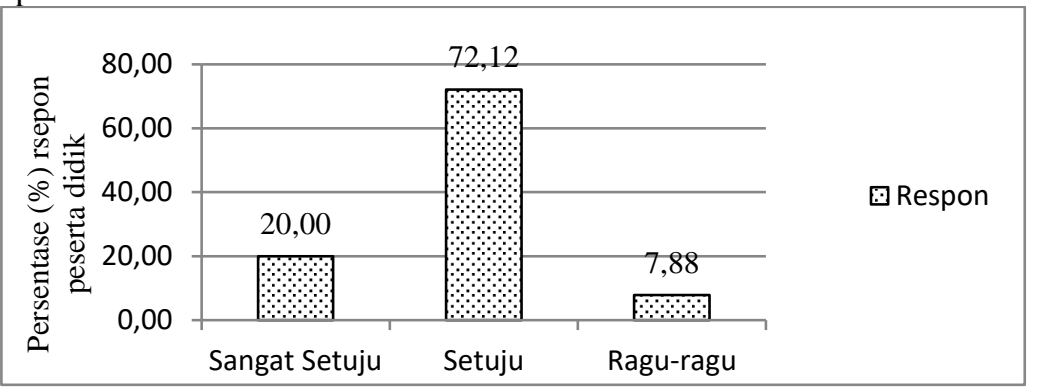

Gambar 3. Persentase respon siswa kelas eksperimen 
Pada Gambar 3 menunjukkan besarnya presentase respon positif siswa tehadap pembelajaran menggunakan model IBL berbantuan media permainan katalist hal ini sejalan dengan penelitian Aprilia, Nuswowati, \& Susilaningsih (2015) bahwa pelajaran kimia dengan menggunakan media pembelajaran berbasis inkuiri memperoleh respon positif dari siswa. Pada penelitian Astyana, Leny \& Saadi (2017) juga menugatakan digunakannya model inquiry pada saat pembelajaran mendapat respon lebih positif dikarenakan siswa sangat termotivasi dan merasa tertarik untuk mengikuti proces belajar.

\section{SIMPULAN}

Kesimpulan dari penyelidikan ini ini yaitu (1) Terdapat perbedaan motivasi siswa, (2) Hasilbelajar pengetahuan yang berbeda, (3) Terdapat hubungan antara motivasi dan hasil belajar pengetahuan setelah diberi perlakuan, (4) Pembelajaran dengann model inquiry based learning (IBL) berbantuan media permainan kata-list mendapatkan respon yang sangan positif.

\section{DAFTAR RUJUKAN}

Aprilia,I. T., Nuswoti, M., Susilaningsih, E. (2015). Pengembangan media flash berbasis pembelajaran inkuiri untuk meningkatkan hasil belajar siswa. Jurnal Inovasi Pendidikan Kimia, 9, 1607-1616.

Astyana, K., Leny., Saadi, P. (2017) Pengaruh model inkuiri terbimbing bervisi sets terhadap keterampilan proses sains dan hasil belajar larutan penyangga siswa kelas XI PMIA SMAN 3 Banjarmasin. Journal of Chemistry and Education, 1, 65-72.

Ekayani, N. L. P. (2017). Pentingnya penggunaan media pembelajaran untuk meningkatkan prestasi belajar siswa, ResearchGate, 1-11.

Farhan, M., \& Retnawati, H. (2014). Keefektifan pbl dan ibl ditinjau dari prestasi belajar, kemampuan representasi matematis, dan motivasi belajar. Jurnal Riset Pendidikan Matematika, 1, 227-240.

Fatonah, D. S. R., Ashadi., \& Haryono. (2016). Studi komparasi pembelajaran kimia menggunakan model inquiry based learning (ibl) dan problem based learning (pbl) pada materi termokimia kelas XI SMAN 1 Sukoharjo dengan memperhatikan kemampuan matematik tahun pelajaran 2015/2016. Jurnal Pendidikan Kimia (JPK), 5, 36-42.

Fitriyani, D., Darwis, Z., \& Kartika, I. R. (2017). Pengaruh pembelajaran inkuiri terbimbing berbasis SETS terhadap hasil belajar kimia pada materi larutan penyangga. Jurnal Riset Pendidikan Kimia, 7, 66-69.

Ismail., Enawaty, E., \& LestariI. (2018). Pengaruh penggunaan media pembelajaran videoscribe terhadap hasil belajar siswa materi ikatan kimia. Jurnal Pendidikan dan Pembelajaran, 7, 1-10.

Jafar, R. A., Side, S.,\& Maryono. (2018). Pengaruh metode everyone is a teacher here terhadap motivasi dan hasil belajar siswa kelas X SMA Negeri 18 Makassar pada materi pokok ikatan kimia. Jurnal Chemica, 19, 36-45.

Nurdin, F., Sulastry, T., Hasri (2018). Pengaruh penggunaan media pembelajaran berbasis macromedia flash 8 pada model pembelajaran kooperatif melalui pendekatan saintifik terhadap motivasi dan hasil belajar (study pada materi pokok laju reaksi). Chemistry education review (CER), 1, 29-43.

Puspadewi , A., \& Syahmani. (2016). Meningkatkan hasil belajar siswa dengan model pembelajaran problem based learning (pbl) berbantuan modul dalam materi larutan penyangga. Quantum Jurnal Inovasi Pendidikan Sains, 7, 19-26. 
Rahmadani, S., Rasmiwetti., Azmi, J. (2015). Penggunaan media permainan ular tangga untuk meningkatkan prestasi belajar siswa pada pokok bahasan hidrokarbon di kelas XI SMA As-shofa Pekanbaru. Jurnal Online Mahasiswa Fakultas Keguruan dan Ilmu Pendidikan, 2, 1-10.

Salam, M., Muharram., \& Aulia, A.(2016). Pengaruh media animasi dalam model pembelajaran think pair share (tps) terhadap hasil belajar siswa kelas X sains SMAN 1 Pinrang studi pada materi pokok ikatan kimia. Jurnal Chemica, 17, 103-112.

Salipah., Sudarmin., Haryani, S. (2016). Pengaruh model pembelajaran inquiry berbantuan playing card terhadap hasil belajar siswa. Chemistry in Education, $5,1-7$.

Septiani, D., Sumarni, W., \& Saptorini. (2014). Efektivitas model inkuiri berbantuan modul dalam meningkatkan pemahaman konsep dan keterampilan generik sains. Jurnal Inovasi Pendidikan Kimia, 8, 1340-1350.

Syah, M. (2003). Psikologi Belajar. Jakarta: Rajawali Press.

Tyas, A. S., \& Lazulva. (2018). Pengaruh inkuiri terbimbing melalui media adobe flash terhadap hasil belajar. Jurnal Tadris kimiya, 3, 182-189. 